\title{
UPAYA ASĀTĪDZ DALAM MENINGKATKAN KEMAMPUAN MEMBACA KITAB KUNING AL-YAQŪT AL-NAFĪS DI MADRASAH ALIYAH
}

\section{ATNA AKHIRYANI, TITIN FATIMAH, ASLAN F LATINGARA}

\author{
Institut Agama Islam Negeri Palu, Indonesia \\ Jl. Diponegoro No. 23, Kec: Palu Barat, Kota Palu, Sulawesi Tengah, 94221, Indonesia \\ Corresponding E-mail: atna.nn90@gmail.com
}

\begin{abstract}
This research aims at finding out the teachers' effort in developing the students' ability in reading Al-Yaqüt Al-Nafis at class two senior high school. This research employed the Descriptive Qualitative method. Its findings indicate an increase in the teachers' effort in developing students' ability in reading and translating Al-Yaqüt Al-Nafiss. The teachers applied sorogan method in the teaching and learning process and applied repetition and practice techniques in learning Al-Yaqūt Al-Nafiss.
\end{abstract}

Key words: Reading Ability, Classic Book.

\begin{abstract}
Abstrak
Penelitian ini bertujuan untuk mengetahui bagaimana upaya Asātīdz dalam meningkatkan kemampuan membaca kitab kuning Al-Yaqūt Al-Nafìs pada kelas II Aliyah. Metode penelitian yang digunakan adalah pendekatan kualitatif deskriptif. Hasil penelitian ini menunjukan bahwa dalam upaya yang di lakukan oleh Asātīdz dalam meningkatkan kemampuan membaca kitab kuning terdapat peningkatan santri terhadap kemampuan membaca dan menerjemahkan kitab kuning Al-Yaqūt Al-Nafiss. Metode yang di gunakan adalah metode sorogan Adapun teknik yang digunakan dalam pembelajara Kitab tersebut adalah teknik pengulangan dan latihan.
\end{abstract}

Kata Kunci: Kemampuan Membaca, Kitab Kuning. 


\section{PENDAHULUAN}

Salah satu lembaga pendidikan Islam di Indonesia adalah pesantren. Dalam sejarah perkembangan pendidikan Islam di Nusantara, pesantren memiliki peran yang sangat penting dalam perkembangan pendidikan Islam. Pada dasarnya peranan pesantren adalah sebagai salah satu lembaga yang memiliki visi dan tujuan untuk mencetak generasi muda Islam agar memahami dan menguasai ilmu-ilmu agama (tafaqquh fi al-din) secara mendalam.

Seiring dengan perkembangan zaman, perubahan sistem pembelajaran telah dilakukan di beberapa pondok pesantren yang pada awalnya menerapkan sistem pembelajaran konvensional, sekarang menerapkan sistem madrasah dengan kelas yang progesif. Pada sistem ini santri dikelompokkan ke dalam kelas dan diperkenankan mengambil pelajaran berikutnya setelah menyelesaikan mata pelajaran dan dinyatakan naik kelas ke jenjang berikutnya. Semua elemen penting pendidikan mulai dari kurikulum, pendekatan, metode, sampai evaluasi hasil belajar diatur secara terencana, dan terkontrol, namun ini hanya berdasarkan pengetahuan lembaga pondok yang bersangkutan saja, sehingga walaupun proses pembelajaran dapat berjalan dengan baik, tetapi tetap ada kekurangan yang dialami, baik dalam segi strategi pembelajaran, kurikulum, potensi guru, indikator pembelajaran atau pun yang lain. Dalam proses pembelajarannya, madrasah ini sudah menggunakan sistem kelas, yaitu santri dikelompokkan dalam suatu kelas menurut kemampuan santri tersebut. Hal ini dilakukan agar proses pembelajaran berjalan dengan baik dan hasil yang dicapai juga optimal karena sesuai dengan kemampuan yang dimiliki santri. Begitu pula proses pembelajaran yang berlangsung di pondok pesantren, seorang kiai atau ustadz dituntut untuk menguasai metode dan strategi pembelajaran yang tepat untuk santrinya, termasuk dalam metode pembelajaran kitab kuning yang dikenal tanpa harakat (kitab gundul). 
Al Bariq : Jurnal Pendidikan Bahasa Arab, 2, (1), 2021, 45-62

Dalam lingkungan pondok pesantren sangat dikenal dengan dengan lingkungan yang sering menggunakan bahasa Arab. Realitas menunjukkan bahwa menguasai pelajaran bahasa Arab tidaklah mudah seperti bahasa ibu atau bahasa pertama karena bahasa Arab merupakan bahasa asing. Bahasa yang dipelajari dan ditelaah oleh masyarakat, baik yang berorientasi pada pendekatan normatif dan spiritualis dengan berkeyakinan bahwa bahasa Arab merupakan bahasa agama karena al-qur'an diturunkan dengan bahasa Arab, maupun melalui pendekatan edukatif dan konsumtif, yang beranggapan bahwa bahasa Arab merupakan bahasa yang patut dikaji secara mendalam untuk mengetahui kajian historis dan estetikanya. ${ }^{1}$

Selain dikenal dengan lembaga pendidikan yang bersinggungan dengan bahasa Arab, buku-buku dan kitab-kitab yang di pelajari di dalamnya banyak menggunakan bahasa arab. Salah satunya di kenal kitab Gundul atau Kitab Kuning

\footnotetext{
${ }^{1}$ Taufik, Pembelajaran Bahasa Arab MI (metode implikatif dan inovatif berbasis ICT). (Surabaya: PMN, 2011), 1.
}

yang dalam penulisanya tidak menggunakan harakat. Olehnya dalam upaya membaca dan menerjemahkan kitabkitab kuning mempunyai tantangan tersendiri bagi setiap santri yang mengenyam pendidikan di pondok pesantren. Karena membaca merupakan dasar untuk menguasai berbagai bidang studi. Karena kemampuan membaca dalam suatu bidang studi melibatkan berbagai aspek termasuk aspek bahasa dan kaidahkaidahnya, yang menjadi modal utama dalam penguasaan untuk mampu membaca kitab klasik.

Dalam hal mempelajari kitab kuning, setiap santri perlu mengerti tehnik-tehnik menerjemahkanya dan juga diperlukan ilmu dasar untuk dapat membaca kitab kuning. Selain itu juga peran seorang ustadz atau guru sangat penting dalam mendorong setiap santri untuk mahir membaca dan menerjemahkan kitab kuning. Keterampilan seorang ustadz dalam mengajarkan metode maupun ilmuilmu dasar dalam menigkatkan kemampuan santrinya membaca kitab 
kuning sangat penting. Pelajaran kitab kuning adalah sebagai salah satu pelajaran agama Islam yang wajib diikuti oleh semua santri yang belajar di pondok pesantren. Dimana pengajaran kitab kuning memberikan pendidikan untuk mengamalkan dan memahami ilmu yang didapat. Agar santri menjadi lebih semangat dalam mempelajari kitab kuning, peran ustādh dan guru sangat penting dalam memotivasi santri. Motivasi itu sangat penting bagi santri. Motivasi dapat menggerakkan dan mendorong santri untuk belajar. Motivasi belajar memiliki hubungan yang erat bagi santri dalam membangkitkan dan mengarahkan mereka untuk mempelajari sesuatu yang belum mereka ketahui. Dengan demikian, agar santri tidak mengantuk, tidak merasa bosan dan memiliki semangat dalam mempelajari kitab kuning perlu adanya dorongan lebih dari ustadz dan guru untuk meningkatkan semangat belajar santri.

Berdasarkan latar belakang di atas, Penulis tertarik untuk mengangkat permasalahan tersebut melalui pendekatan teoritis dan empiris guna mengetahui “Upaya Asātīdh dalam Meningkatkan Kemampuan Membaca Kitab Kuning AlYaqūt Al-Nafìs di kelas II Aliyah Pondok Pesantren Raudhatul Musthafa Lil Khairaat Desa Kanuna Kabupaten Sigi”

\section{A. Kemampuan Membaca}

\section{Kemampuan Membaca}

Kemampuan berasal dari kata mampu yang bearti kuasa, sanggup melakukan sesuatu, dapat. $^{2}$ Berdasarkan kata dasar mampu, kemampuan dapat diartikan sebagai suatu keadaan atau kondisi yang menunjukkan sanggup atau dapat melakukan sesuatu.

Membaca merupakan salah satu keterampilan berbahasa. Membaca merupakan kegiatan memahami teks bacaan dengan tujuan untuk memperoleh informasi dari teks yang kita baca. Membaca didefinisikan sebagai kegiatan atau proses yang berupaya untuk menemukan berbagai

${ }^{2}$ Desi Anwar, Kamus Bahasa Indonesia Modern, (Surabaya: Amelia Surabaya, 2002), 233. 
informasi yang terdapat dalam

tulisan. $^{3}$

Menurut Ruddell dalam Morrow

$$
\text { mendefinisikan membaca }
$$

sebagai salah satu dari penggunaan

berbahasa untuk menguraikan tulisan

atau simbol dan memahaminya.

Dijelaskan juga oleh Tampubolon

bahwa membaca merupakan kegiatan

fisik dan mental untuk menemukan

makna dan tulisan. Menurut Bond

dalam Abdurrahman membaca

merupakan pengenalan simbol-simbol

bahasa tulis yang merupakan stimulus

yang membantu proses mengingat

tentang apa yang dibaca untuk

membangun suatu pengertian melalui

pengalaman yang telah dimiliki.

Berkaitan dengan pelajaran

bahasa Arab, Membaca merupakan

salah satu keterampilan dalam bahasa

Arab yang di kenal dengan Mahara

Alqiraah. Yang dalam

implementasinya Mahara Alqiraah

${ }^{3}$ Dalman, Keterampilan Membaca, (Cet. II; Jakarta: Rajawali, 2014), 5. mendorong peserta didik untuk dapat mengasah kemampuan membaca teksteks berbahasa arab dan juga mampu menerjemahkan ke dalam bahasa indonesia.

Hakikat membaca menurut Ahmad Izzan yang dikutip oleh Rosyidi dalam buku "Memahami Konsep Dasar Pembelajaran Bahasa Arab" Membaca adalah melihat atau memahami isi dari apa yang tertulis dengan melisankan atau di dalam hati dan mengeja atau melafalkan apa yang tertulis. Jadi, membaca mencakup dua kemahiran sekaligus, yaitu; mengenal simbol-simbol tertulis yang ada di dalamnya dan memahami isinya. ${ }^{4}$

Ada beberapa kemampuan yang harus dimiliki dan otomatis kemampuan tersebut menjadi tujuan dalam membaca bahasa Arab pada umumnya dan membaca kitab Kuning pada khususnya. Adapun kemampuan tersebut sebagai berikut :

${ }^{4}$ Abd Wahab Rosyidi dan Mamlu'atul Ni'mah, Memahami Konsep Dasar Pembelajaran Bahasa Arab (Malang, UIN Malik Perss:2012), 95. 
Al Bariq : Jurnal Pendidikan Bahasa Arab, 2, (1), 2021, 45-62

a. Memampuan membedakan Pembelajaran Nahwu Di huruf dan kemampuan Pondok Pesantren Raudhatul mengetahui hubungan antara Mustofah Lilkhairat”. lambang dan bunyi.

Bahwasanya Sorogan yang

b. Kemampuan mengenal kata berarti sorong atau sodor dalam kalimat dan tidak dalam kalimat.

dalam bahasa Indonesia.

Dalam bahasa Arab dikenal

c. Memahami kata sesuai dengan konteksnya.

dengan istilah Tikrar (pengulangan). Metode

d. Memahami kata sesuai dengan arti asli dari kata tersebut.

sorogan yang di maksudkan disini adalah apa yang

e. Mengetahui hubungan logis dan penggunaan kata penghubung dalam suatu kalimat.

f. Menyimpulkan isi dari bacaan tersebut dengan cepat. ${ }^{5}$

telah diajarkan oleh guru dicek kembali. Jika santri yang menyorong itu sudah dianggap bagus, maka santri tersebut bisa dipromosikan menjadi naib

\section{Metode Membaca Kitab}

a. Metode Sorogan

bagi sang guru. Dapat juga dikatakan metode sorogan ini Menurut Muljono yang di kutip oleh Muhammad Jabir dalam jurnalnya yang berjudul "Efektivitas Metode Sorogan Terhadap

5 Abdul Hamid, Mengukur Kemampuan Bahasa Arab Untuk Studi Islam (Cet. II; Malang: UIN Malik Pers, 2013), 63.

dengan istilah metode evaluasi. Biasanya santri yang sudah bagus bacaanya atau sudah menguasai materi-materi yang telah diwetonkan kepadanya. Kemudian dengan metode 
Al Bariq : Jurnal Pendidikan Bahasa Arab, 2, (1), 2021, 45-62

sorogan teruji bahwa santri

tersebut sudah menguasainya

dengan baik, maka besar

kemungkinan materi-materi

selanjutnya, walaupun belum

diwetonkan kepadanya akan

dikuasai secara otomatis. ${ }^{6}$

Metode ini diawali dengan

kyai/pendidik membacakan

kitab dan menerjemahkan

satu persatu. Kemudian Santri

mengulangi apa yang kyai

baca tadi secara individu atau

satu persatu menghadap. ${ }^{7}$

b. Metode Komunikatif

Metode komunikatif atau

yang lebih dikenal dengan

sebutan CLT (communicative

language teaching) maka,

pada metode ini tema

pembahasan harus jelas dan
${ }^{6}$ Muhammad Jabir dan Wahyu, Efektivitas Metode Sorogan Terhadap Pembelajaran Nahwu di Pondok Pesantren Raudhatul Mustofah Lilkhairat. ( Jurnal di terbitkan, jurusan Pendidikan Bahasa Arab, IAIN dato karama, Palu, 2020), 13-24.

Acep Hermawan, Metodologi Pembelajaran Bahasa Arab (Bandung: Remaja Rosdakarya, 2011), 220. terbatas. $^{8}$ Pada metode ini yang lebih aktif dalam proses pembelajaran adalah peserta didik, pendidik hanya sebagai fasilitator saja.

\section{Jenis-jenis Membaca}

Jenis-jenis membaca pada bahasa Arab dalam hal ini dikhusukan membaca kitab maupun pada membaca secara umum, dapat diklasifikasikan menjadi dua macam, yakni:

a. Membaca dari segi penyampaian

1) Membaca nyaring (Qiro'ah Jahriyah) Membaca dengan menekankan kepada aktifitas anggota/peserta didik berbicara mengeluarkan bunyi sesuai dengan tulisannya ada.

8 Abd Wahab Rosyidi dan Mamlu'atul Ni'mah, Memahami Konsep Dasar Pembelajaran Bahasa Arab (Malang, UIN Malik Perss:2012), 9394. 
Al Bariq : Jurnal Pendidikan Bahasa Arab, 2, (1), 2021, 45-62

2) Membaca dalam hati serta penguasaan tata (Qiro'ah Shomitah) bahasa.

Membaca dengan melihat huruf dan memahami bacaan tanpa mengeluarkan bunyi (tanpa aktifitas organ bicara). ${ }^{9}$

- Terdapat bimbingan, arahan dan pemantauan oleh pendidik dalam hal kemajuan peserta didik.

b. Membaca dari segi bentuknya

2) Membaca ekstensif Jenis membaca dari sebgi bentunya antara lain:

(Qiro'ah muassa'ah), menurut rosyidi

1) Membaca intensif membaca ekstensif (Qiro'ah mukatstsafah), menurut rosyidi membaca intensif memiliki memiliki karakteristik sebagai berikut:

- Kegiatan dilakukan karakteristik sebagai di luar kelas.

berikut;

○ Memiliki tujuan

- Dilakukan di kelas bersama pendidik meningkatkan pemahaman isi

- Memiliki tujuan bacaan.

meningkatkan

- Pendidik

keterampilan menentukan, membaca dan mengarahkan materi memperkaya pembendaharaan kata 
Al Bariq : Jurnal Pendidikan Bahasa Arab, 2, (1), 2021, 45-62

bacaan, kemudian

mendiskusikannya. ${ }^{10}$

\section{Indikator Membaca Kitab}

Indikator peserta didik dapat

membaca kitab kuning dengan

baik, menurut Khairul Umam yang

dikutip oleh Sofi Hasanah antara

lain:

a. Ketepatan Dalam Membaca

Ketepatan membaca dilihat

dari ketepatan penempatan

kaidah-kaidah/aturan bahasa

arab dan cara bacanya.

Kaidah tersebut antara lain,

berupa Nahwu dan Shorof

nya.

b. Pemahaman Mendalami Isi

Bacaan Aktivitas membaca

tidak berhenti pada

pembacaan teks saja. Akan

tetapi, dituntut untuk

memahami isi berupa; ide

pokok/gagasan dan pokok

pikiran yang dikehendaki

penulis. c. Dapat Mengungkapkan Isi

Bacaan Setelah dapat

memahami isi kitab tersebut,

maka peserta didik dituntut

untuk dapat mengungkapkan

isi dari kitab tersebut dengan

Bahasa mereka sendiri. ${ }^{11}$

\section{Kitab Yaqutun Nafis}

Kitab Al-Yaqūt Al-Nafiss atau judul panjangnya Al-Yaqūt Al-Nafis

fi Mazhab Ibn Idris fi Fiqh Al-Sadat

Al-Syafi'iyyah merupakan sebuah

kitab fiqh dalam mazhab al-Syafi'i.

Kitab ini merupakan sebuah karya

yang disusun oleh al-'Allamah al-

Sayyid Ahmad bin 'Umar al-

Syathiri (1312-1360H), seorang

ulama mazhab al-Syafi'i yang

terkenal pada zamannya.

Kandungan kitab ini membahas

hampir keseluruhan pembahasan

tentang bab fiqh dalam mazhab al-

Syafi'i, namun permbahasan secara

${ }^{11}$ Sofi Hasanah Fitrianur, Impelementasi Metode Sorogan Modified Dalam Meningkatkan Kemampuan Membaca Kitab Kuning Di Pesantren Luhur Sabilussalam Ciputat, (Skripsi di terbitkan, Jurusan Pendidikan Agama Islam, UIN Syarif Hidatullah, Jakarta, 2014), 11. 
ringkas. Kitab ini, dianggap sebagai

kitab matan fiqh dalam mazhab alSyafi'i, yang mudah ibaratnya. Untuk memudahkan para pembacanya memahami kitab ini, Sayyid Ahmad al-Syathiri telah menyediakan beberapa penjelasan ringkas yang berbentuk hawasyi dan takliq bagi beberapa perkataan dan permasalahan yang dibahas dalam kitab tersebut.

Kitab ini telah dicetak berulang kali dan menjadi teks pengajian fiqh al-Syafi'i di kebanyakan negara Islam. Kitab Al-Yaqūt AlNafis ini, telah dibuat uraiannya (syarah) oleh Syaikh al-Habib Muhammad bin Ahmad bin Umar al-Syathiri (1422 H) dengan judul “ Syarh Al-Yaqut Al-Nafis fi Mazhab Ibn Idris ". Beliau merupakan anak dari pengarang kitab Al-Yaqut AlNafis, yaitu al-Sayyid Ahmad alSyathiri. ${ }^{12}$

${ }^{12}$ https://irtaqi.net/2018/02/27/mengenalkitab-al-yaqut-nafis/. Di akses pada 20 Mei 2021
Dalam muqaddimah, pengarang menjelaskan 10 dasar-dasar suatu bidang ilmu tertentu agar pelajar mana pun mendapatkan basis yang kokoh untuk menyerap ilmu secara maksimal dan menguasai aspek ontologis, epistemologis, maupun aksiologisnya.

Isi kitab Al-Yaqūt Al-Nafìs ini akan dijelaskan sebagai berikut: (a) Hukum-hukum agama islam, bersuci, benda-benda yang najis, istinja', wudlu, mandi tayamum, haid dan nifas, (b) Shalat, rukunrukun shalat, sunnah-sunnah shalat, hal-hal yang membatalkan shalat dan makruhnya, shalat-shalat sunnah, shalat jama'ah, shalat kedua hari raya, shalat jenazah. (c) Zakat, zakat fitrah, (d) Puasa, (e) Haji, (f) Umroh, (g) Qurban, (h) makanan yang dihalalkan dan diharamkan, (i) Jual-beli, (j) Riba, (k) Nikah (l) Talaq (cerai), (m) Warisan dan lain-lain. 
Upaya Asātidh dalam Meningkatkan

Kemampuan Membaca Kitab Kuning AlYaqūt Al-Nafīs

Pondok pesantren Raudhatul Musthafa Lil Khairaat adalah sebuah lembaga pendidikan Islam yang tujuan utama di gagas oleh Habib Idrus bin Ali Alhabsyi untuk menyebarluaskan ilmu agama Islam, terutama dalam bidang pendidikan. Pondok tersebut merupakan Pondok Salafiyah bermazhab Syafi'iyah yang belajar khusus tentang ilmu agama. Dan Pondok tersebut banyak menggunakan kitab kuning dalam setiap pembelajaran yang di lakukan baik dari tingkat dasar maupun tingkat atas. Salah satu kitab yang di gunakan adalah kitab Al-Yaqūt Al-Nafiss, yang di ajarkan pada kelas II Aliyah. Olehnya peneliti merasa perlu melihat seperti apa proses atau upaya yang di lakukan dalam meningkatkan kemampuan membaca kitab kuning.

Melihat dari persoalan di atas yakni pondok tersebu banyak menggunakan kitab kuning, maka setiap Asātidh selalu berupaya dalam meningkatkan pemahaman tentang pembacaan kitab kuning, Salah satunya di kelas II Aliyah pada pondok pesantren tersebut. Peran Asātidh sangat penting dalam peningkatan pembelajaran membaca kitab kuning, salah satunya kitab Al-Yaqūt Al-Nafìs.

Usaha dalam melakukan peningkatan kemampuan membaca kitab kuning selalu menjadi prioritas pada kelas II Aliyah. Ada beberapa kegiatan yang di lakukan oleh Asātidh dalam meningkatkan kemampuan santri.

1. Memastikan bahwa setiap santri dapat membaca Al-Qur'an dengan baik dan benar.

2. Menekankan kepada setiap santri untuk dapat menguasai Ilmu Nahwu, Sharaf serta Mufradat.

Untuk pembelajaran Nahwu sendiri, kitab yang di gunakan itu bertahab. Mulai dari menghafal mat'nu Aljurumiah, kemudian mempelajari syarahnya dan mutamimmahnya dan berakhir pada penghafalan matan 
Alfiyah Ibnu Malik yang berjumlah seribu bait.

3. Kemudian ketika ingin melakukan pembelajaran, maka Asātidh selalu berupaya untuk menekankan kepada santrinya agar tidak pernah izin dalam mengikuti pembelajaran kitab.

4. Membangun komunikasi dengan santri-santri yang telah di kirim untuk belajar di pondok pesantren Dārul Musthafa Hadramaut yaman, tentang cara-cara dalam membaca kitab kuning.

5. Selalu melakukan evaluasi terhadap kemampuan santri membaca kitab kuning.

Pada tahapan ini, peneliti melihat ada upaya yang di lakukan Asātidh dalam meningkatkan kemampuan membaca kitab kuning Al-Yaqūt Al-Nafìs di setiap melakukan pertemuan. Dan dari respon santri terhadap proses pembelajaran di kelas II Aliyah menunjukan adanya perkembangan dalam pembelajaran.
Selanjutnya, dalam melakukan pembelajaran bahasa Arab, dalam hal ini membaca kitab kuning seorang Ustādh perlu menggunakan metode yang tepat. Agar proses belajar mengajar dapat berjalan dengan baik.

Dalam kegiatan observasi dan wawancara yang peneliti lakukan, bahwa penggunaan metode pembelajaran yang diterapkan dikelas II Aliyah untuk meningkatkan kemampuan membaca kitab kuning $A l$ Yaqūt Al-Nafis, menggunakan metode Sorogan.

Metode sorogan dipandang salah satu metode yang efektif untuk mengembangkan kemahiran membaca kitab kuning, karena penerapan metode ini didasarkan pada tujuan pengajaran pembacaan tulisan arab yang tanpa harakat, dengan menitik beratkankan gramatika bahasa Arab, seperti nahwu, sharaf, dan mufradatnya.

Pelaksanaan pembelajaran kitab kuning dengan menggunakan metode sorogan cukup sederhana, yakni: Santri Membaca materinya dahulu kemudian menerangkan, 
lalu tanya jawab antara Ustadh dan santrinya kemudian dites sejauh mana kefahamannya.

Jadi, penggunaan metode Sorogan dalam pembelajaran kitab kuning sangat penting dalam meningkatkan pemahaman para santri dalam mengusai keterampilan membaca kitab kuning di kelas II Aliyah pondok pesantren Raudhatul Musthafa Lil Khairaat.

Berdasarkan hasil observasi dan wawancara yang di lakukan peneliti, bahwa penggunaan teknik yang diterapkan dikelas II Aliyah untuk meningkatkan kemampuan para santri agar bisa mengasah kemampaun memaca kitab kuning dan dapat mengusai kitab Al-Yaqūt Al-Nafìs. Yakni menggunanakan teknik pengulangan dan latihan.

Hasil wawancara penulis dengan narasumber dapat dijelaskan bahwa teknik pengulangan dan latihan ini digunakan untuk memperkuat materi yang diberikan kepada para santri sehingga para santri dapat memahami secara saksama dan mengingat kembali materi yang telah disajikan kepada mereka dari ustadz tersebut.

Jadi penggunaan teknik pengulangan dan latihan dalam pembelajaran di kelas II sangat penting untuk meningkatkan pemahaman para santri guna meningkatkan kemampuan santri dalam membaca kitab kuning Al-Yaqūt Al-Nafìs.

Dari uraian di atas, penulis melihat dari upaya yang di lakukan oleh Asātīdh dalam meningkatkan kemampuan membaca kitab kuning Al-Yaqūt Al-Nafis, penggunaan metode sorogan dalam melaksanakan pembelajaran serta teknik yang di gunakan adalah teknik pengulangan dan latihan. Maka untuk menjawab pertanyaan yang peneliti masukan dalam rumusan masalah yakni apakah upaya yang di lakukan dapat meningkatkan kemampuan membaca kitab kuning Al-Yaqūt Al-Nafiss. maka peneliti melihat ada peningkatan yang terjadi. Hal itu peneliti temukandari hasil pengamatan peneliti di lapangan, Dan di dasari pada indikator berikut ini : 
a. Ketepatan Santri dalam membaca. Ketepatan membaca dilihat dari ketepatan penempatan kaidahkaidah/aturan bahasa arab dan cara bacanya. Kaidah tersebut antara lain, berupa Nahwu dan Shorofnya.

b. Pemahaman santri mendalami isi bacaan. Aktivitas membaca tidak berhenti pada pembacaan teks saja. Akan tetapi, dituntut untuk memahami isi berupa; ide pokok/gagasan dan pokok pikiran yang dikehendaki penulis.

c. Santri dapat mengungkapkan isi bacaan. Setelah dapat memahami isi kitab tersebut, maka peserta didik dituntut untuk dapat mengungkapkan isi dari kitab tersebut dengan Bahasa mereka sendiri.

Berdasarkan hasil wawancara yang peneliti lakukan di atas dan di sertai data nilai kelas II Aliyah, bahwa peneliti meyakini kebenaran informasi yang di sampaikan. Maka hasil dari penelitian ini dalam upaya yang di lakukan Asātīdh dalam meningkatkan kemampuan membaca kitab kuning Al-Yaqūt Al-Nafis di kelas II Aliyah, dapat menunjukan peningkatan terhadap santri.

Kendala dan solusi dalam Pembelajaran Kitab Kuning di Kelas II Aliyah Pondok Pesantren Raudhatul Musthafa Lil khairaat.

Dalam kaitanya terhadap peningkatan membaca kitab kuning di kelas II Aliyah Pondok Pesantren Raudhatul Musthafa Lil Khairaat. Terdapat kendala-kendala yang di hadapi dalam proses pembelajaran. Berdasarkan hasil obervasi dan wawancara penulis di lokasi penelitian tersebut, terdapat beberapa kendala yang harus dihadapi serta solusi yang ditempuh sebagaimana yang telah disampaikan oleh salah satu ustadz sebagai berikut :

"kendala yang saya rasakan yaitu, kurangnya minat sebagian santri di kela dalam setiap pembelajaran. Ada santri yang tidak mengitu pembelajaran sebelumnya, maka ketika dia masuk di pertemuan selanjutnya dia pasti tidak paham materi yang sebelumnya di pelajari, dan juga kendala yang terpenting yaitu kurangnya penguasaan kosa kata"13

Beliau juga mengatakan bahwa dalam pembelajaran yang di lakukan, kendala

\footnotetext{
${ }^{13}$ Rafli Safinah, ustadh Pondok Pesantren Raudhatul Musthafa Lil Khairaat Kota palu, "wawancara", tanggal 18 Maret 2021
} 
yang di dapati dari santri itu sendiri.

Misalnya :

1. Keinginan santri untuk belajar membaca kitab kuning, jika keinginan membaca kitab kuning santri kuat maka proses pembelajaran pun berjalan efektif

2. Motivasi santri, motivasi santri sangat penting sekali, dengan adanya motivasi santri dari dirinya sendiri maka santri akan mau melakukan pembelajaran membaca kitab kuning.

3. Kesungguhan santri, jika seorang santri sungguh-sungguh maka pembelajaran kitab kuning pun tidak akan mersa terbebani.

4. Keadaan fisik santri, jika keadaan fisik santri baik maka pelaksanaan pembelajaran pun akan efektif. ${ }^{14}$

Ada beberapa santri yang penulis

wawancarai terkait kesulitan yang mereka

temui saat belajar. Di antranya mereka

mengungkapkan :

"saat belajar membaca kitab kuning, kadang kami mendapat kendala dikarenakan sebelumnya tidak melakukan murojaah, hal ini di karenakan rasa mengantuk karena kelelahan di tambah dengan ada tugas-tugas dari mata pelajaran lain"15

Adapun solusi yang bisa ditawarkan dalam

pembelajaran di kelas II Aliyah. Yakni

dengan cara selalu melakukan pengawasan

\footnotetext{
${ }^{14}$ Rafli Safinah, ustadz Pondok Pesantren

Raudhatul Musthafa Lil Khairaat Kota palu, "wawancara", Via WhatsApp (online), tanggal 16 April 2021

${ }^{15}$ Ahmad Nurrohim, santri Pondok Pesantren

Raudhatul Musthafa Lil Khairaat Kota palu,

"wawancara", tanggal 18 Maret 2021
}

terhadap setiap santri pada saat jam pelajaran maupun saat waktu Murojaah, selalu memberikan dukungan dan motivasi kepada santri.

Hal itu seperti yang telah di kemukakan oleh Ustādh Rafli :

"solusi yang saya lakukan ketika menemukan permasalah dari sorang santri, yaitu dengan cara mengawasi mereka pada saat waktu murojaah di malam hari. Selain itu juga saya memotivasi mereka dengan menceritakan pengalaman-pengalaman para penuntut ilmu. Dan terkadang jika saya mendapati santri yang malas, saya menyuruh dia untuk menulis materi. Hal itu agar santri secara perlahan mengingat apa yang telah dia tulis "16

Dari hal-hal yang telah peneliti uraikan di atas, bahwa dalam setiap pembelajaran akan selalu menemukan kendala. Baik itu dari santri, maupun dari yang lainya. Akan tetapi solusi yang di tawarkan dapat membantu mengurangi kendala yang terjadi pada saat pembelajaran.

\footnotetext{
${ }^{16}$ Rafli Safinah, ustadh Pondok Pesantren Raudhatul Musthafa Lil Khairaat Kota palu, "wawancara", tanggal 18 Maret 2021
} 


\section{Kesimpulan}

Berdasarkan hasil penelitian dan pembahasan dapat di tarik kesimpulan. Yaitu:

1. Upaya yang di lakukan Asātidh dalam meningkatkan kemampuan membaca kitab kuning al-Yaqūt al-Nafìs, sebagai berikut :

a. Memastikan bahwa setiap santri dapat membaca Al-Qur'an dengan baik dan benar.

b. Menekankan kepada setiap santri untuk dapat menguasai Ilmu Nahwu, Sharaf serta Mufradat.

c. ketika ingin melakukan pembelajaran, maka Asātidh selalu berupaya untuk menekankan kepada santrinya agar tidak pernah izin dalam mengikuti pembelajaran kitab.

d. Membangun komunikasi dengan santri-santri yang telah di kirim untuk belajar di pondok pesantren Dārul Musthafa Hadramaut yaman, tentang cara-cara dalam membaca kitab kuning. e. Selalu melakukan evaluasi terhadap kemampuan santri membaca kitab kuning.

Dalam upaya yang di lakukan oleh Asātidh untuk meningkatkan kemampuan membaca kitab kuning, menggunakan metode sorogan. yakni para santri satu persatu datang menghadap Ustādh dengan membawa kitab tertentu. Selanjutnya Ustādh membacakan kitab tersebut beberapa baris atau kalimat demi kalimat dengan maknya. Setelah selesai santri mengulang bacaan tersebut sampai dirasa cukup dan bergantian dengan yang lainnya. Adapun teknik yang di gunakan menggunakan teknik pengulangan dan latihan.

2. Indikator yang di gunakan dalam mengukur peningkatan kemampuan membaca kitab kuning al-Yaqūt alNafis di kelas II Aliyah Ponpes Raudhatul Musthafa Lil Kairaat. Hal ini di lihat sebagai berikut:

a. Ketepatan Santri dalam membaca 
b. Pemahaman santri mendalami isi bacaan

c. Santri dapat mengungkapkan isi bacaan

\section{DAFTAR PUSTAKA}

Arikunto, Suharsimi. Prosedur Penelitian Ilmiah Suatu Pendekatan Praktek. Cet. IX; Jakarta: Cipta, 1993.

Armai, Arief. Pengantar Ilmu dan Metodologi Pendidikan Islam. Jakarta: Ciputat Perss 2002.

Azizah Fatimah Binti. "Upaya Peningkatan Kualitas Membaca Kitab Kuning Melalui Pembelajaran Bahasa Arab di Pondok Pesantren Bahru Ulum Probolinggo" Skripsi diterbitkan, Jurusan Pendidikan Agama Islam, UIN Maulana Malik Ibrahim, Malang, 2008.

Andi Prastowo, Metode Penelitian Kualitatif dalam Perspektif Rancangan Penelitian. Jogjakarta: Ar-Ruzz Media, 2016.

Abd Wahab Rosyidi dan Mamlu'atul Ni'mah, Memahami Konsep Dasar Pembelajaran Bahasa Arab. Malang: UIN Malik Perss:2012.

Abdul Hamid, Mengukur Kemampuan Bahasa Arab Untuk Studi Islam. Cet. II; Malang: UIN Malik Pers, 2013.

Acep Hermawan, Metodologi Pembelajaran Bahasa Arab. Bandung: Remaja Rosdakarya, 2011.
Basrowi dan Suwandi, Memahami Penelitian Kualitatif. Jakarta: Rineka Cipta, 2008.

Bruinessen, Martin Van. Kitab Kuning Pesantren dan Tarekat. Bandung : Mizan, 1995.

Dalman, Keterampilan Membaca. Cet. II; Jakarta: Rajawali, 2014.

Departemen Pendidikan Nasional. Kamus Besar Bahasa Indonesia. Jakarta: Balai Pustaka, 2012.

Hadi, Sutrisno. Metodologi Research Jilid 1. Cet. XXIX; Yogyakarta: Ahdi Yogyakarta, 1997.

Ismail Usmani Asep. Menguak yang Ghaib Khasanah Kitab Kuning, Jakarta: Hikmah, 2002.

Jabir Muhammad dan Wahyu, Efektivitas Metode Sorogan Terhadap Pembelajaran Nahwu di Pondok Pesantren Raudhatul Mustofah Lilkhairat. Jurnal di terbitkan, jurusan Pendidikan Bahasa Arab, IAIN dato karama, Palu, 2020.

Moleong, Lexy J. Metodologi Penelitian Kualitatif. Jakarta: PT Rineka Cipta, 1998.

Muhammad Taufik, "Metode Pembelajaran Kitab Kuning di Pondok Pesantren Sunan Giri Krasak Kec. Argomulyo Kota Salatiga" Skripsi di terbitkan, Jurusan Pendidikan Agama Islam, IAIN Salatiga, Salatiga, 2016.

Narbuka, Chalid dan Ahcmadi. Metodologi Penelitian. Cet. IV; Jakarta: Bumi Aksara, 2002. 
Nurcholish Madjid. Bilik-Bilik Pesantren, Sebuah Potret Perjalanan. Jakarta: Paramadina, 1997.

Peter Salim dan Yeni Salim, Kamus Besar

Bahasa Indonesia, Jakarta: Modern English Press, 2005.

Pusat Bahasa Depdiknas. Kamus Besar Bahasa Indonesia. Jakarta: Balai Pustaka, 2005.

Prastowo Andi. Metode Penelitian Kualitatif dalam Perspektif Rancangan Penelitian, Jogjakarta: Ar-Ruzz Media 2016.

Rosyidi, Abd. Wahab \& Mamlu'atul Ni'mah. Memahami Konsep Dasar Pembelajaran Bahasa Arab. Malang: UIN-Maliki Press, 2011.

Sugiyono. Metode Penelitian Kuantitatif Kualitatif dan $R \& D$, Bandung: Alfabeta 2009.

Sofi Hasanah Fitrianur, "Impelementasi Metode Sorogan Modified Dalam Meningkatkan Kemampuan Membaca Kitab Kuning Di Pesantren Luhur Sabilussalam Ciputat" Skripsi di terbitkan, Jurusan Pendidikan Agama Islam, UIN Syarif Hidatullah, Jakarta, 2014.
Subagyo, P. Joko. Metode Penelitian Dalam Teori dan Praktek. Cet IV; Jakarta: Rinaka Cipta, 2004.

Sanjaya, Wina. Strategi Pembelajaran Berorientasi Standar Proses Pendidikan, Jakarta: Kencana Prenanada Media Grup, 2006.

Taufik. Pembelajaran Bahasa Arab MI (Metode Implikatif dan Inovatif Berbasis ICT). Surabaya: PMN, 2011.

Takdir, Mohammad. Modernisasi Kurikulum Pesantren, Yogyakarta: IRCiSoD, 2018.

Undang-Undang Republik Indonesia No. 20 Tahun 2003, Tentang Sistem Pendidikan Nasional, Bandung: Citra Umbara, 2003.

Wahid, Abdurrahman. Pesantren Masa Depan; Wacana Pemberdayaan dan Transformasi Pesantren, Bandung: Pustaka Hidayah, 1999.

Yasmadi. Modernisasi Pesantren, Kritik Nurcholish Madjid Terhadap Pendidikan Islam Tradisional. Jakarta: Ciputat Press, 2002. 